\title{
Countering Ideological Support for Terrorism in Europe: Muslim Brotherhood and Hizb ut-Tahrir-Allies or Enemies?
}

\section{Zeyno Baran *}

Since the events of 11 September 2001, Western efforts to counter ideological support for terrorism have primarily focused on defeating $\mathrm{Al}$ Qaeda and its violent allies. Many strategists have argued that the "Global War on Terror" or the "Long War" really is a war against "Islamist terrorism" or "(violent) jihadism." Almost all of the Sunni extremists that are members of groups falling under these rhetorical umbrellas are drawn from the conservative Wahhabi/Salafi tradition of Islam, but not all Wahhabi/Salafi individuals and organizations promote violence. Ergo, the argument goes, one can divide and conquer the enemy by strengthening those Wahhabi/Salafi groups that denounce violence, so that they would then confront their violent brethren. This thinking has led policy makers across Europe (and the United States) to conclude that groups like the Muslim Brotherhood and Hizb ut-Tahrir, which are Islamist in orientation but do not necessarily call for terrorist acts, could be "engaged" and turned into "allies" in this war. ${ }^{2}$

This paper argues against this approach, and suggests that strategies based on such a framework will certainly lead to defeat in the "war of ideas," since they mistake the nature and ultimate goals of the enemy. The deciding factor in choosing allies in this war cannot be based on tactics - that is, on whether or not a group has chosen to pursue violent methods. Rather, it must be based on ideology, on whether a group is Islamist or not. That means, in essence, that a non-violent, British-born, seemingly successfully integrated Islamist cannot be considered an ally in this struggle. However, an ultra-conservative Muslim immigrant to Europe-one who does not even speak any Western languages, but rejects Islamist ideology—can be.

It is not possible to counter a powerful ideology without offering a better one. There is simply no easy or quick remedy to a problem (radical Jihadism) that has emerged as a combined result of decades of concerted efforts on the part of the Islamists and failed policies on the part of the Europeans. A comprehensive and longterm strategy that addresses both these challenges is needed. Therefore, this essay will

* Zeyno Baran is Senior Fellow and Director of the Center for Eurasian Policy at the Hudson Institute in Washington, D.C.

1 Recent books discussing jihadism include: Mary Habeck, Knowing the Enemy: Jihadist Ideology and the War on Terror (New Haven, CT: Yale University Press. 2006); Efraim Karsh, Islamic Imperialism: A History (New Haven, CT: Yale University Press, 2006); and Andrew G. Bostom, ed., Legacy of Jihad: Islamic Holy War and the Fate of Non-Muslims (Amherst, NY: Prometheus Books, 2005).

2 Based on author's discussions with European and American government officials throughout 2006. In this context, the term Islamist is used to refer to groups that advocate for the use of Islam (and Sharia, or Islamic law) as the only basis for the legal and political system that governs the economic, social, and judicial mechanisms of the nation-state. 
first discuss the "ideology of the enemy” by focusing on two of Europe's strongest and fastest growing Islamist organizations: the Muslim Brotherhood and Hizb ut-Tahrir. In the second part, the article will discuss Europe's failed integration models that created the ideological vacuum that made it possible for these Islamist groups not only to find refuge in Europe, but also to make it a stronghold of extremism.

\section{Inability to Define the Enemy and the Threat}

Even though over five years have passed since 9/11, there is still no common definition of the "enemy," since there is still no clear understanding of who or what is being fought in this "war." The term Islamofascism came close, but it only made sense to a relatively small group of academics, analysts, and policy makers that properly understood the concept. ${ }^{3}$ In the correct sense, the term refers to the advent of a totalitarian ideology seeking global domination that has cloaked itself in religious terminology (in this case, Islamic), thereby posing an even greater ideological threat to the West than atheistic communism ever did.

The inability in Western societies to define the enemy is in part due to the challenge policy makers face in disseminating their message to multiple audiences. The concept of Islamofascism resonated with those who understood how the ideologies of fascism (of which Nazism was the most virulent strain) and communism had taken such a strong hold over otherwise reasonable people that they literally cheered murderous activities as being necessary to achieving the overarching goal of each movement. Similarly, the current global challenge is a powerful ideology that has caused countless otherwise reasonable Muslims around the world to cheer acts of terrorism.

Yet, how does one communicate the nature of such an adversary to the millions of Muslims who have never studied nor had a reason to hear about the destruction caused by these other totalitarian ideologies? How many European Muslims know this history? When even secular, democratic, and largely Westernized Turks are not taught the history of World War II, thus leaving them unable to understand the dangers of the wide circulation of Hitler's Mein Kampf in their country, how can one expect impoverished Muslims in the slums of Pakistan or Morocco to comprehend what "Islamofascism" means? To them, any term that combines "Islam" and "fascism" is a clear sign that their religion is being attacked, validating claims that "the war on terrorism" is indeed a euphemism for "the war on Islam."

In fact, Islamists are constantly struggling to ensure that it is not just the poor and uneducated members of the Muslim community, but all of the world's Muslims that consider their faith and identity to be under attack. They often do so by reminding their audiences of U.S. President George W. Bush's unfortunate statement in the days after

3 President Bush first used the term on 6 October 2005 in a speech at the National Endowment for Democracy; available at www.whitehouse.gov/news/releases/2005/10/20051006-3.html. See also Stephen Schwartz, “What is 'Islamofascism'?” The Weekly Standard (17 August 2006); available at http://www.weeklystandard.com/Content/Public/Articles/000/000/012/ 593ajdua.asp. 
9/11: "This crusade, this war on terrorism, is going to take a while." ${ }^{4}$ To Islamists, this was indeed a declaration that America was waging the final phase of a Western war against Islam that had begun in the medieval era. An increasing number of Muslims even believe that the United States is orchestrating the sectarian killings in Iraq, hoping that a Shiite-Sunni religious war will keep the umma (the global Muslim community) bogged down in internal strife. As long as this ideology continues to reach Muslim hearts and minds, there can be no end to Islamist terrorism.

There is a continuing debate within Islamist groups whether or not to utilize acts of terrorism and violence, but this is primarily a debate about tactics, not about principles. Most non-jihadi groups—such as Tablighi Jamaat, Hizb ut-Tahrir, the Muslim Brotherhood (or al-Ikhwan al-Muslimun), and Jamaat al-Islami-all claim to be nonmilitant, but in reality are unwilling to condemn acts of terrorism. They not only do nothing to oppose violence, they even teach, preach, and promote militant ideology. Moreover, they are neither bound by constraints of time (their view holds that they can be in this "long war" for many decades) or location (the new caliphate that is their goal can be established anywhere, including in Western Europe). Hence, many do not see a need to resort to terrorism during this "long war," since they are not seeking to achieve short-term effects.

The Islamist threat is a result of decades of networking, infrastructure building, and intellectual and ideological preparation. These groups have spent billions of dollars in creating networks of like-minded supporters, and have worked hard at social engineering (i.e., Islamization) for nearly four decades. Their work begins with the Islamization of education (and thus of the individual), then of the family unit, and finally of society. It also includes the Islamization of history, juxtaposing the glorious past of Islam with the injustices Muslims have faced over the centuries, and stressing the ability to bring down an empire if Muslims are united (according to the Islamist explanation for the fall of the Soviet Union). Thanks to mass communication media and new technologies, Islamists are now much more effective in bombarding young Muslims with these messages. Furthermore, the Islamist revolutionary vanguard is no longer limited to the Arabic-speaking Middle Easterner; the Islamists and terrorists of today and tomorrow are the smart, tech- and-media-savvy citizens of the West.

Europe has served as a particularly fertile ground for these efforts; in fact, Western Europe today represents the ideological center of Islamism. Many of Europe's Muslims believe that Islam is compatible with secular and liberal democracy as well as with basic civil liberties. However, the Islamists argue that Muslims must live only under Islamic laws, and push for the establishment of parallel societies-including the introduction of sharia, or Islamic law. These Muslims often belong to an ideological network that is using politicized Islam to drive a wedge between Muslims and non-Muslims in Europe-an effort in which they are currently succeeding.

4 President George W. Bush, "Remarks by the President Upon Arrival," 16 September 2001; available at www.whitehouse.gov/news/releases/2001/09/20010916-2.html. 
Two of these movements, the Muslim Brotherhood and Hizb ut-Tahrir, are by far the most effective groups in Islamist circles in Europe, and they continue to grow. Given the confusion many in the West have about the ideology and strategy of these two organizations, some even are trying to "engage" them and turn them into allies in countering ideological support for terrorism. The next section will review the basic key aspects of each group's ideology before demonstrating that they are not a solution to the problem, but in fact are at its core.

\section{The Ideology and Goals of the Muslim Brotherhood and Hizb ut-Tahrir}

Those policy makers who argue that the Muslim Brotherhood is a "moderate" organization seem to disregard its ideology, history, and strategy. They even seem to disregard the Brotherhood's own statements. The following excerpt from its "Official English Website," www.ikhwanweb.com, is instructive:

To confront the Western and U.S. domination, the Muslim Brotherhood thinks that fighting domination requires adopting several factors, including:

1. Spreading Islamic concepts that reject submission to humiliation, and incite to fighting it, and to be on to rise to support the oppressed.

2. Reviving the will of liberation and independence in the peoples, and sowing the spirit of resistance.

3. Supporting Hamas government with all spiritual and material and with experience; to spare the Palestinian people's need for Western countries which are biased against its freedom and interests.

4. Forming an international relation and a public opinion that fights injustice and seeks establishing rights, justice and peace in the world.

5. Activating the economic boycott against imperialist states, and also boycotting their cultural production.

6. Achieving political, economic and social internal reform, and removing the food and technological gaps with imperialist states.

7. Working on correcting the image of Islam among Westerners, and clarify the truth of our fair causes, and removing the deformed image about Islam and Muslims.

8. Spreading popular movements in Europe and South America opposing US domination.

It is true that most Ikhwanis do not directly call for terrorist acts, are open to dialogue with the West, and participate in democratic elections. Yet this is not sufficient for them to qualify as "moderate," especially when their ideology is so extreme. As an example, their often-quoted motto declares that, "Allah is our objective, the Prophet is our leader, the Koran is our law, jihad is our way, dying in the way of Allah is our highest hope.”

The Muslim Brotherhood emerged in 1928, four years after the Ottoman caliphate was abolished. In trying to answer "what went wrong" within Islam that allowed the caliphate to fall, Sayyid Qutb-an Egyptian author and bureaucrat who was the movement's key ideologue - was inspired by the works of the thirteenth-century thinker Ibn Taymiyya and his eighteenth-century ideological successor Muhammad Ibn Abd alWahhab. He thus believed that the Islamic world's decline could be reversed, but only 
if a small group of "real” Muslims emulated the ways of the Prophet Muhammad and worked to replace existing governments in Muslim lands with Islamic regimes. Accordingly, followers of Qutb desire the overthrow of their current governments; once this is accomplished, they plan to declare armed jihad against non-Muslim states. They believe that it is the duty of all Muslims to bring about such change so that they can remedy the decline of Muslim societies around the world.

The Muslim Brotherhood network first came to Europe in the 1950s, following the severe crackdown against the group after its failed attempts to overthrow Middle Eastern governments. When Saudi Arabia established the Muslim World League in 1962 in order to spread the teachings of Wahhabism, funds started flowing into Brotherhoodled mosques and other dawa (preaching) activities. While at first Europe was seen as a base from which the group could launch its struggle against Middle Eastern regimes, it soon became another front for the spreading of Brotherhood ideology. ${ }^{5}$

Even more extremist than the Brotherhood is Hizb ut-Tahrir, which was created in 1953 by Taqiuddin al-Nabhani, a former Ikhwani from Jerusalem. He left the Brotherhood because he found its ideology to be too moderate, and too accommodating of the West. Hizb ut-Tahrir (HT), which translates as "Party of Liberation," seeks to "liberate” Muslims from Western influence (whether cultural, economic, political, or social) so that they are "free" to bring back Islamic rule. HT holds that Western civilization and Islam are mutually exclusive systems vying for ideological dominance within Muslim societies. The only way to reestablish the kind of Islamic society promulgated by the Prophet is to "liberate" Muslims from the thoughts, systems, and laws of kufr (nonbelievers), and replace the Judeo-Christian-dominated nation-state system with a borderless umma ruled by a new caliph. HT believes in the need for "re-education" of Muslims so that they reject previously held ideologies-whether nationalism, socialism, Western democracy and culture, etc-in favor of an Islamic one. ${ }^{6}$

HT's ideology is simple, and is aimed at unifying the umma. Whereas many other Islamist groups insist that only their particular religious interpretation is valid, or focus on a single issue (such as Palestine or Kashmir) to the exclusion of all others, HT maintains its focus on a broader goal of uniting all Muslims under the Islamist banner. It thus emphasizes issues of more general concern, such as the so-called clash of civilizations and the injustices suffered by Muslims worldwide.

HT's key objective, which has not changed for over half a century, is to overthrow existing governments (thus removing the artificial barriers separating Muslim states) and form a transnational Islamic state ruled by an elected caliph. To reach this goal, HT envisions a three-step social engineering process: forming small cells to patiently

5 For a detailed review of the Muslim Brotherhood in Europe, see Lorenzo Vidino, “Aims and Methods of Europe's Muslim Brotherhood,” in Current Trends in Islamist Ideology, Vol. 4 (Washington, D.C.: Hudson Institute, November 2006); available at www.futureofmuslim world.com/research/pubID.55/pub_detail.asp.

6 Zeyno Baran, "Hizb ut-Tahrir. Islam’s Political Insurgency” (Washington, D.C.: The Nixon Center, December 2004); available at http”//www.eurasianpolicy.org/files/publications/ Political_Insurgency.pdf. 
disseminate ideas, targeted specifically at a cadre of elites in government, military, and academic circles; widening these cells to disseminate HT's dawa in order to bring ideological unity to society; and finally, when a critical mass is achieved, taking revolutionary action, i.e. overthrowing the government. The caliph will then be charged with further disseminating Islamic teaching through dawa and militant jihad. Clearly, HT's methodology in pursuit of these goals is clandestine, as it is not possible to work openly towards the overthrow of governments.

As an organization, HT officially opposes active participation in militant jihad prior to the establishment of the caliphate. There is, however, an exception to this position: if "infidels" attack a Muslim country, then members of HT living in that country are required to resist. Since, in HT's view, no truly Muslim country exists today, HT members are thus not obligated to participate in militant jihad. However, in the context of the current global campaign of jihadist activity, there is internal disagreement over whether to maintain the traditional gradualist approach to infiltration and revolution or to embrace more activist policies. As a result, HT members have recently been allowed to wage jihad, provided that they do so as individuals rather than as group members.

The Party of Liberation views the United States as the cultural "occupying” power in the Muslim world, and hence sees the U.S. as its main enemy. This reasoning is crucial to the justification of terrorist attacks against American targets. Recent HT publications have included titles such as "Attack of the West to destroy Islam as an Ideology and System." Others promote the idea that, since the U.S. declared a "war on Islam," jihad against Americans and Jews is acceptable. These publications are read widely by HT's dispersed membership, and circulate easily via the Internet. One core book studied by recruits preparing for membership is entitled Terrorism, which provides a detailed justification for the use of violence. HT thus acts as an incubator for extremism, preparing future terrorists with its ideology, propaganda, and recruitment process. I have thus described it in the past as a "conveyor belt" for terrorism.

While HT and the Muslim Brotherhood diverge in their tactics, the two movements have convergent ideological and strategic aims. There are two main differences between the two groups, and these are both tactical in nature. First, in pursuit of their long-term goals, the Brotherhood works with governments, while HT seeks to overthrow them. Second, they target different sectors of society: the Brotherhood recruits at the grassroots level, while HT appeals to the intellectually curious and well educated. Given their core beliefs and objectives, and considering the global context in which they operate, it should be obvious that neither of them can become true allies of the West in the "long war" against jihadist terror.

\section{The Threat in Europe}

Both the Muslim Brotherhood and Hizb ut-Tahrir pose a serious threat to the social fabric of Europe, especially in countries with large Muslim populations. Europe's difficulty in absorbing and assimilating its Muslim populations-not just immigrants, but also those whose parents and even grandparents were born on European soil-has left many Muslims without a sense of belonging or any clear identity. Both the Muslim 
Brotherhood and HT have been increasingly able to provide both; when people join these groups, they are definitively part of the umma.

These Islamist movements take advantage of freedoms of speech, assembly, and the like to spread hate-filled, anti-Semitic, and anti-constitutional ideas. In the process, they actively and openly create a fifth column of activists working to undermine the very systems under which the Western societies live. They are also working to create self-segregated societies, in a process that has been called "voluntary apartheid." This process has been enthusiastically supported by the Muslim Brotherhood, whose unofficial spiritual leader Yusuf al-Qaradawi has repeatedly advised European Muslims (from his base in Qatar) that they need to create their own "Muslim ghettos" to avoid the risk of cultural assimilation. If assimilation can be avoided, sharia law can eventually be introduced to govern these separate societies.

Having perfected their methodology and rhetoric for the intellectual and political struggle in the West, Hizb ut-Tahrir and the Muslim Brotherhood are showing themselves to be much more effective than Western governments in the war of ideas and in the competition for the hearts and minds of Europe's Muslims. The next generation of terrorist facilitators produced by them will accordingly be even more dangerous: smart, educated, technically skilled, comfortable operating in Western societies, and able to interact with the media.

As mentioned earlier, groups like Hizb ut-Tahrir and the Muslim Brotherhood are engaged in a long-term social engineering project, whereby they hope to lead Muslims to reject Western norms of pluralism, individual rights, and the rule of law. It is therefore critically important to recognize that at the core of Islamist terrorism is the ideological machinery that works to promote sedition and hatred. While the West can successfully defeat active terrorists, responding effectively to threats posed by these more ideologically and socially oriented groups is far more difficult, especially if they are not directly involved in violence. If no action is taken, then Islamist networks will continue to grow across Europe.

\section{How to Counter Islamism in Europe?}

The prevailing view-that Islamists should be co-opted into existing political systems-simply will not work. The fallacy in this policy of appeasement lies in assuming that an individual or group that sounds moderate in fact is moderate. Often, Islamists are willing to make superficial concessions while continuing to hold an uncompromising worldview-one that they share with fellow Muslim audiences when they are confident that the West is not paying attention.

Islamists also cannot be weakened using a "divide and conquer" strategy. While Islamist groups do compete over Muslim recruits in Europe, and while they often bear considerable animosity towards one another, they will respond to such a strategy by uniting under the umbrella of the umma. This is precisely what happened when Prime Minister Tony Blair decided to proscribe HT after the 7 July 2005 bombings in London: HT reached out to the various Islamist organizations, including the Muslim Brotherhood (despite their history of differences), and urged them to stand united, or "be the next in line to be proscribed." It is particularly unfortunate that British 
Islamists succeeded in uniting, while various government entities tasked with addressing the challenge of extremism are more divided than ever before.

So what can be done? The starting point must be a broader recognition that Europe (like the U.S.) is confronting a thriving ideological movement-one that has been wellfunded for decades, during which time it has established networks, mosques, schools, charities, and other organizations in pursuit of a social engineering project on a global scale. The debate on how to counter ideological support for terrorism therefore has to focus on the political insurgency inside Europe, before it becomes a violent uprising.

Once this is recognized, then European policymakers and intellectuals will start posing tougher questions to the self-declared "Muslim spokesmen," rather than accepting their assurances of "moderation" at face value. ${ }^{7}$ They will also begin enforcing laws against seditious activity and hate speech. In cases in which existing laws are not applicable, then amendments will be introduced. And they will find many Muslim allies along the way-especially those who are concerned about their children being sucked into a self-destructive ideology, along with millions of secular and liberal Muslims who prefer to live their lives as individuals, rather than members of a monolithic umma.

While taking a firm stand against Islamists is critical in countering ideological support for terrorism, this approach will have only partial success unless Muslims in Europe genuinely want to become "Europeans," and are welcomed as such. To win the hearts and minds of their Muslim citizens, Europe needs to become something that they want to become a part of-something more attractive to them than the umma.

\section{A New Framework: Tolerant Integration}

Central to the challenge posed by radicalism is the decades-long inability of European states to promote lasting integration of their Muslim citizens. European governments have so far pursued two principal approaches: multiculturalism and assimilation. On one end of the spectrum is the model of multiculturalism (pursued primarily in the Netherlands and the U.K.), which calls for embracing the cultural diversity of all the peoples of Europe, including the growing Muslim immigrant communities. Casting its net of acceptance too wide, this policy resulted in the toleration of beliefs and practices that are entirely at odds with European values, including honor killings and the preaching of hatred by imams. On the other end is the model of assimilation (adopted mainly in France), which ignores cultural and religious differences in order to forge a national identity based on common civic ideals.

Neither of these approaches, nor the intermediate approaches adopted by countries such as Denmark and Germany, has worked well. Instead, rooted as they are in a common attitude of indifference towards European Muslims, they have produced a dual sense of alienation — both secular and spiritual—that is most prevalent among second-

7 Martin Bright, "When Progressives Treat with Reactionaries: The British State's Flirtation with Radical Islamism,” Policy Exchange (July 2006); available at www.policyexchange.org. uk/images/libimages/176.pdf. 
and third-generation European Muslims. ${ }^{8}$

The brutal murder in November 2004 of Dutch filmmaker Theo van Gogh and the London subway bombings in July 2005 underscored the shortcomings of the policies of multiculturalism in the Netherlands and the United Kingdom, in which well-intentioned efforts to embrace immigrants" "cultural diversity" resulted in the social, economic, cultural, and political marginalization of Muslim communities. Despite official efforts to discourage discrimination, many Dutch and British Muslims felt excluded from the mainstream cultural lives of their countries due to an official doctrine that defined them in terms of their religious affiliation. And many first-generation immigrants, finding no incentives or pressures to participate as citizens, quickly reconciled themselves to their exclusive affiliation as members of an ethnic or religious community outside of the mainstream. Meanwhile, as the November 2005 outbreak of rioting throughout France has demonstrated, the official French policy of remaining largely unconcerned with the religious and cultural identities of its citizens has also failed to avert the problem of marginalization. In short, Europe's failure to integrate its Muslim communities has helped to create immigrant ghettoes where poverty, unemployment, discrimination, and prejudice serve to cut off European Muslims from society as a whole. These populations then become easy prey for Islamist recruiters such as the Muslim Brotherhood or Hizb ut-Tahrir.

Islamists also take advantage of the spiritual alienation plaguing many second- and third-generation immigrants in Europe's Muslim ghettoes. Angry about perceived injustices to Muslims in domestic and international politics, many of these marginalized individuals yearn for spiritual fulfillment. Yet their communities often lack imams and religious instructors of local origin, leaving these European Muslim youth susceptible to propaganda and sermons that preach a narrow and hateful strain of Islam. Indeed, Islamists have for several decades built mosques in the Muslim ghettoes of European cities, and have staffed them with imams trained in the Wahhabi/Salafi schools of Islam.

The Muslim Brotherhood and HT take advantage of both kinds of alienation that lead to an identity crisis among European Muslims. They argue that, since Muslims will never be fully accepted as “European,” Europe's Muslims need to be proud of their Muslim identity and do not need to integrate into the social and political life of their European nations. To immigrant populations facing social exclusion, they provide a strong sense of community through their comprehensive local networks, which form virtual parallel societies. Meanwhile, to those in search of a spiritual direction, they provide easy, straightforward answers to challenging questions-answers that invaria-

8 I have given several briefings to U.S. and European officials on this dual sense of alienation, and am currently working on a book that will address the issues outlined in this section. Some of these concepts have already been incorporated into U.S. Department of State official language. See, for example, Daniel Fried, Assistant Secretary for European Affairs, “Overview of Islamist Extremism in Europe,” Testimony before the Subcommittee on European Affairs of the Senate Foreign Relations Committee, Washington, D.C. (5 April 2006); available at www.state.gov/p/eur/rls/rm/64192.htm. 
bly reflect the extremism of their ideology.

In light of the clear failure of existing policies of Muslim integration, it is in the security interests both of the United States and of Europe to find viable alternatives. A more effective and durable strategy for governments would be to pursue a model of tolerant integration, an approach that would combine a tough approach toward radical Islamism with a soft approach to Muslims at large. Over time, this approach could lead to the development of a new school of thought, a "European Islam" that reconciles the tenets of the religion with the democratic and liberal principles of Europe. Caught between the radicalism of its own Enlightenment and the radicalism of modern Islamism, Europe desperately needs such a new approach-a "European way" by which it can encourage its 20 million Muslims to become full European citizens, while refusing to compromise its fundamental principles.

\section{Growth of the Problem: Alienation of Muslims}

As the postwar "economic miracle" reached Northern Europe in the 1950s and 60s, the rate of economic growth in Europe was vastly outstripping the rate of population increase, creating a huge demand for unskilled labor. This resulted in the "guest worker" phenomenon, whereby large numbers of workers from Mediterranean countries—notably from the least-developed parts of Turkey and Morocco-were brought to countries such as Germany and the Netherlands on temporary contracts. Accordingly, governments did not pursue a conscious integration policy, seeing the newcomers in strictly economic terms. As the Swiss author Max Frisch famously noted, "We called for workers, but we got human beings.",9

Although guest workers were at first expected to return to their homelands, the introduction of family reunification programs soon permitted them to build ethnicallybased communities in the countries in which they worked. However, given that many Muslims were not encouraged to learn local languages or to obtain further education, over time the emerging minorities increasingly found themselves on the margins of society. Confined to poor neighborhoods, most had little choice but to remain in lowpaying jobs, with little room for advancement.

Despite being born in Europe, the second and third generations remained in a similarly disadvantageous situation, with lower levels of education, higher rates of unemployment, and lower incomes than the population as a whole. This lack of opportunity was compounded by legal difficulties (unlike in the United States, citizenship in most European countries is not automatically extended to all individuals born there) as well as by discrimination and prejudice from the local populations. Furthermore, many of these immigrants lacked support networks to help them integrate into European societies. The 2005 civil unrest in France brought to light the immense frustration that had built up over decades among the disaffected minority communities living in the Paris suburbs, most of which are made up of second- or third-generation European Muslims.

9 Max Frisch, Introduction to Alexander J. Seiler, ed., Siamo Italiani-die Italiener: Gespräche mit italienischer Gastarbeitern (Zurich: E.V.Z. Verlag, 1965). 
Moreover, long after they had established roots in Europe, Muslims continued to be labeled as "foreigners" by mainstream society, inhibiting the growth of a European identity and leading to a profound sense of alienation. These feelings of alienation have been a prime cause of the trend towards radicalization among European Muslims. Denied the chance to be European, many have taken pride in an identity that has given them a sense of belonging - that of a Muslim, and a member of the umma.

Indeed, as mentioned earlier, since the 1970s Europe has become a prime recruiting ground for Islamist groups like the Muslim Brotherhood and Hizb ut-Tahrir. Unable to develop their organizations or spread their ideas in their home countries due to repressive government policies, radical imams and activists from the Middle East moved to Europe to take advantage of the permissive legal environment (especially the freedoms of speech and assembly). In mosques and schools, these ideologues recruited followers among the disaffected European Muslims. In time, these strengthened extremist groups were able to re-export their ideology back to their countries of origin. Until recently, Europeans tacitly permitted this activism; under an implicit "covenant of security," radical Islamists based in Europe could do whatever they wished in the Muslim world, so long as they did nothing to destabilize their host nations.

Years of neglect by European governments have in turn allowed these Islamists to perfect a variety of recruitment measures. Targeting the particularly vulnerable college student population, groups like HT have been able to elude attempts by university authorities to impose oversight by registering organizations under false names and by setting up recruiting stalls outside campus grounds. They also distribute propaganda at mosques and Islamic community centers, using them as indoctrination facilities. The Internet is also used as a means of approaching the younger, technologically-literate generation of Muslims who-in the absence of any spiritual guidance from their elders-are relying upon so-called "cut-and-paste Islam," named for the selective fashion in which radicals present certain Islamic teachings, removed from their broader religious context, as a basis for their faith.

Ultimately, it is not poverty or lack of education that leads Europe's Muslims to extremism - rather, it is the sense of alienation, rooted in issues of secular and religious identity. Many of the radical Islamists of Europe are from educated, middle-class backgrounds (among them, the 7/7 London bombers). Most are men, although women can also become extremists, including suicide bombers; in a recent report the Dutch General Intelligence and Security Service (AIVD) highlighted a marked rise in the number of women who are becoming radicalized. ${ }^{10}$ A notable example is that of Muriel Degauque, a 38-year-old Belgian woman from a troubled background who carried out a suicide attack against U.S. forces in Iraq. There are other European-born converts to radical Islam, such as the convicted "shoe bomber" Richard Reid, born in London to an English mother and a Jamaican father; Reid converted to Islam while in prison in his early 20s. The majority of Europe's Muslim extremists do not have a madrassa

10 AIVD, "Violent Jihad in the Netherlands" (2006), 39; available at www.aivd.nl/contents/ pages/65582/jihad2006en.pdf. 
education or a personal stake in the conflicts of the Middle East, yet all share the same sense of being marginalized by European society.

The London subway and bus bombings conclusively demonstrated that devastating attacks can be carried out on European soil by outwardly well-integrated middle-class Muslims. They also demonstrated that Europe's future, if radical Islamism goes unchecked, may look bleak. In Britain, following the July 2005 bombings, a classified MI5 document discussed the possibility of a "home-grown Islamic insurgency" that would be followed by a serious backlash against Muslims in the U.K. ${ }^{11}$ Later on, a report by the AIVD analyzed the potential for conflict involving the Muslim minority, and concluded that many of the conditions that have fostered violence in other countries are also present in the Netherlands. These conditions include the presence of a destructive, exclusive ideology within segments of the Muslim community; the widespread perception of injustice; the absence of a shared narrative between the minority and the majority; the prevalence of dehumanization of the "other"; and the mutual feelings of anger and victimization among both groups, along with the resulting desire for revenge. At the moment, the West is simply unable to handle the problem at hand.

\section{Existing Approaches and Limitations}

As discussed above, Europe so far has utilized two principal policy responses to immigration. The multicultural approach, used primarily in the U.K. and the Netherlands, seeks to acknowledge the cultural, ethnic, and religious diversity of a nation's citizens and allows immigrant communities to maintain their cultural affiliation and identity, while remaining free to devise their own means of integrating with mainstream society. Though attractive in principle, this model is ultimately based on a mixture of "passive tolerance" and "passive intolerance," and has failed in both of its aims: to eliminate intolerance among the indigenous population, and to achieve integration of the immigrant population. Accordingly, the two main proponents of multiculturalism are moving away from the approach. Shaken by the brutal 2004 murder of filmmaker Theo van Gogh by an Islamist extremist, the Netherlands is now instead urging immigrants to adopt "Dutch values" in order to obtain residency. Similarly, the 7/7 bombings in the U.K. have led to a partial rejection of multiculturalism in that country.

Assimilation, the second approach, is usually associated with France, though it was adopted in part by countries such as Denmark, Germany, Italy, and Spain that opted for intermediate models also including elements of multiculturalism. Assimilation seeks to minimize cultural and religious differences in order to promote a unifying national identity based on common citizenship and common values. While also attractive in principle, this approach has also proven difficult to achieve in practice. Due to restrictions on the ways in which the government can classify its citizens, French authorities are not completely aware of the number of Muslims in France, and have no way of quantifying (let alone rectifying) the significant levels of economic and educational

11 Raymond Whitaker and Francis Elliott, "Intelligence chiefs warn Blair of home-grown 'insurgency,,” The Independent (7 August 2005); available at http://news.independent.co.uk/ uk/politics/article304303.ece. 
discrimination that French Muslims face. Furthermore, the government's insistence on maintaining a uniform secular civic identity led to the controversial "headscarf law" of 2004, which bans the wearing of conspicuous religious symbols in public schools (while the law applies to all conspicuous religious symbols, it was prompted by Muslim schoolgirls' desire to wear head coverings to school). Many Muslims believe, moreover, that their economic needs are being ignored as well. Frustration has therefore risen to a boiling point, as demonstrated by the widespread riots that began in the heavily Muslim suburb of Paris, Clichy-sous-Bois, in late October of 2005.

In France, the debate about the failure of assimilation has not yet begun in earnest. Unlike in the Netherlands and the United Kingdom, where the prevailing model of managing immigration came under criticism as early as the 1970s, the French have continued to cherish the principles of assimilation, and have avoided expressing genuine understanding of the unique conditions faced by French Muslims. Even as news of those conditions finally began to reach the headlines in the autumn of 2005, Interior Minister Nicolas Sarkozy only exacerbated the situation by using the vulgarism $\mathrm{ra}$ caille ("scum") to describe the crowds of immigrant youth.

However, after the riots finally ended, a consensus began emerging on the need to do a better job in addressing the socio-economic requirements of the residents of the banlieues. These measures, which include economic-development programs, job-creation initiatives, and improved social services, are intended to help French Muslims prosper and ultimately integrate with local economies. The question remains: will France attempt to hold on to its strict emphasis on assimilating into the national culture, or will it compromise in an effort to better integrate its Muslim population?

In general, regardless of the model of integration, European governments until recently did not recognize the need for Muslims to play a meaningful and respected role in the civic and political life of their countries of residence. Many European countries are only now beginning a painful debate over the indifference they have shown toward their Muslim communities, reflecting a deep prejudice that European values must be applied only to "native” Europeans.

Europeans have also only gradually begun to recognize and to try to reverse the trend toward spiritual alienation among Muslims. However, they are hampered by their lack of theological knowledge about Islam and a dearth of European-based theological authority to shape religious attitudes within Muslim communities. This frequently leaves Europeans incapable of distinguishing moderates from extremists who cloak themselves in tolerant rhetoric.

Ultimately, Europe needs a comprehensive new approach of "tolerant integration," one that combines necessary actions against radicalism with efforts to build trust with European Muslim communities. If European governments fail to include Muslims themselves in their efforts to contend with the problem of integration, they risk undermining the legitimacy and weakening the effectiveness of any eventual policy approach, thus allowing the dangerous sense of resentment to continue to fester in marginalized Muslim communities. Moreover, the risk of dangerous resentment extends further still; as discussed below, a failure to develop and implement an inclusive, broad-based approach will only encourage the growing trend toward a disastrous anti- 
Muslim backlash in Europe. And this in turn will further validate the arguments of the Islamists that there is indeed a "war on Islam" under way in the West.

\section{Rousing the Sleeping Giant: Promoting Integration while Preventing a Backlash}

In the early 1990s, as European peoples and governments began to accept the reality of the permanent Muslim presence in Europe, many politicians and intellectuals on the right began to criticize the prevailing dogma of multiculturalism. According to these critics, the policy of multiculturalism sowed the seeds of demographic disaster. Calling attention to the dramatic increase in segregation, especially the rise of Muslim ghettoes in major cities, they argued that this demographic trend posed a threat to the social fabric of their countries. To these observers, the inclusive rhetoric of multiculturalism concealed a reality of exclusion and indifference. Since most immigrants either belonged to the working class or to the ranks of the unemployed, their paths and those of Europe's commercial, cultural, and political elites never crossed-thus allowing elites to cling to their myth of an inclusive society. However, the indigenous lower classes knew better, since it was to their neighborhoods that immigrants were flocking. While fleeing to the new suburbs, the "native" working-class Europeans brought with them their sense of fear, uneasiness, and even hatred toward the new arrivals.

Yet, in the political and cultural climate that prevailed at the time, any negative reference to immigration or immigrants was dismissed as racism, and placed outside the bounds of acceptable political discourse. As early as 1968, Enoch Powell (a leading British Conservative politician) decided that it would be a "betrayal" of his constituents to maintain his silence. In what would later be known as the "Rivers of Blood" speech, he spoke out against the dangers of continued immigration of non-white residents of Commonwealth countries to Great Britain. However, despite considerable displays of public support (ranging from a series of strikes in London's docklands to a wave of over 100,000 letters of support), he was dismissed from his position in the shadow cabinet, and never again assumed a leadership role in politics. Over time, tension mounted between second-generation immigrants, who were not satisfied with life in segregated communities, and working-class indigenous Europeans, who saw immigrants as economic competitors determined to impose a foreign way of life on the local population. Yet the taboo against any debate that might potentially be branded as "racist" remained so pervasive that Europe's political class did not respond to these growing tensions.

All of this changed with September 11. Suddenly, the taboos broke down, and open debates began to take place about Muslim immigration and integration. With their cultural tradition of frankness and outspokenness, the Dutch were particularly enthusiastic in beginning this discussion. Leading the newly emboldened critics of multiculturalism was the flamboyant former university professor Pim Fortuyn, who took the debate to a new level by calling Muslims part of a "fifth column" in European society. His strident anti-immigration message struck a chord among the Dutch population, including among homosexuals, who felt threatened by the increasingly vocal presence of homophobic orthodox Muslims in their midst. When Fortuyn was murdered in 2002, the debate temporarily cooled, as the suspect was an environmental activist, and not, as 
some had initially feared, a Muslim fanatic. Yet, when film director Theo van Gogh was brutally murdered by a Moroccan-Dutch Muslim less than two years later, the gloves truly came off in Dutch political and social debate. With the taboos entirely effaced, all of the mainstream political parties in the Netherlands soon adopted elements of Fortuyn's platform.

While not all those concerned with the rise of Islamist radicalism were opposed to multiculturalism, support for a new approach continued to grow. Partly encouraged by American commentators, critics accused Europe not only of having forgotten its core values and principles but also of lacking the backbone to defend those principles. Throughout Europe, the tone of the debate seemed to change; indeed, had Enoch Powell delivered his speech in the United Kingdom of 2005 rather than 1968, he would not have forfeited his political career. Prominent intellectuals and politicians-such as Michel Gurfinkiel in France, and Frits Bolkestein and Ayaan Hirsi Ali in the Netherlands - argued that Europe had simply become too soft and too morally relativist to put up a credible defense against the coherent and dynamic threat of radical Islam. Representing these strong fears, former European Commissioner Bolkestein argued that "migration and demography" could make Europe part of the Arab world, causing "the relief of Vienna in 1683 [to] have been in vain.”12

In response to political pressure, Europe's governments finally began to adopt new policy measures, many of which centered on the theme of "toughness," such as tighter immigration laws and increased deportations. While they were correct to point out the danger of indifference toward Europe's rising immigrant populations, advocates of these forms of toughness only partially understood the need for reform. They correctly emphasized the concept of a Leitkultur (dominant culture) in European societies, and the need for immigrants to adapt to it, but they neglected the need for this culture to be inclusive. After all, if membership in the Leitkultur is based solely on ethnicity, then migrants will be forever consigned to outsider status. ${ }^{13}$ Yet both sides of the debate saw the Leitkultur only in this narrow sense-as a call for a stronger ethno-national identity. Because of this rough-edged drive to assimilation, second- and third-generation immigrants are feeling pushed into a corner, potentially resulting in a new wave of Islamist radicalization.

Although the emphasis on producing frank evaluations and achieving results marks an improvement over the "anything goes" approach of multiculturalism, these new "tough" measures are too focused on short-term criminal justice measures rather than on long-term structural policies. They also foster a charged political atmosphere, in which emotional responses prevail over dispassionate analysis. In short, while there is a need to compensate for decades of a multiculturalist policy of good intentions, the

12 “Dutch Commissioner Again Warns on Turkish EU Bid,” Turkish Daily News (8 September 2004); available at www.turkishdailynews.com.tr/archives.php?id=37601.

13 The term Leitkultur was first introduced by Bassam Tibi in his 1998 book entitled, Europa ohne Identität, Die Krise der multikulturellen Gesellschaft. Since then Tibi has published many articles and books defining the term further in an effort to suggest a more successful Muslim integration model. 
new emphasis on assimilation is beginning to overcompensate for it. In fact, the pendulum has swung far to the other side, where Muslims are increasingly seen as part of a "fifth column" in European society.

\section{Bridging the Gap}

As described above, neither multiculturalism nor assimilation has succeeded in effectively integrating the Muslims of Europe. Instead, both have led to a sense of alienation and an identity crisis among second- and third-generation Muslims, who are at risk of being pulled into Islamist networks like the Muslim Brotherhood and Hizb ut-Tahrir. While governments are finally recognizing the need to develop more effective models of integration, this recognition is coming at a time when European Muslims feel increasingly distant from the social structures of their countries of residence. Moreover, some of the tough measures recently taken by European governments have only risked making the situation worse.

While it may sound obvious that there is a link between failed integration and the resulting resentment on the one hand, and radicalism and extremism on the other, it has been extremely difficult for European authorities to put this knowledge into practice by devising policies that both effectively defend the democratic order and at the same time invite Muslim communities to participate as full citizens. Every counterterrorist, antiimmigration, or strict integrationist measure, if badly presented or wrongly executed, risks further alienating Muslim communities in Europe, adding to the reservoir of anger and despair that radicalization feeds on. At the same time, too much leniency risks giving away too much public space to intolerant extremists, at a time when radical Islam is already a very powerful force. By giving ground to extremism, Europe's core values of democracy, human rights, and respect for individual freedom of choice would be placed in great danger.

At present, Europe is in need of an approach of tolerant integration, an approach that balances firmness in the defense of the democratic order with a more serious effort at building societies in which immigrant communities can find a secure place. Moreover, Europe is in search of practical ways to nurture a new "European Islam," a form of the religion distinct in its respect for European principles and values. In this new approach, Europe must move away from the exclusive shared narratives of its nationalist past, and allow for differences of ethnicity, religion, and outlook to be included under a broader concept of what it means to be European. It should have a firm and non-negotiable core of political and social principles, but should also feature an outer shell that is porous enough to allow "us" and "them" to come together. Although it will be a difficult balancing act to reconcile the non-negotiable with the porous, the essence of the European project has been reflected in its motto: In Varietate Concordia (Unity in Diversity).

In sum, a new tolerant integration model needs to include the positive aspects of the multiculturalist and assimilationist approaches, while rejecting the negative elements. In Europe, the battle for the hearts and minds of Muslims can be won and the appeal of Islamist ideology can be fought only through such a comprehensive framework. 
WINTER 2006

\section{Bibliography}

Baran, Zeyno. Hizb ut-Tahrir. Islam's Political Insurgency. Washington, D.C.: The Nixon Center, 2004.

Bright, Martin. "When Progressives Treat with Reactionaries: The British State's Flirtation with Radical Islamism." Policy Exchange (2006).

Habeck, Mary. Knowing the Enemy: Jihadist Ideology and the War on Terror. New Haven, CT: Yale University Press, 2006.

Schwartz, Stephen. "What is 'Islamofascism'?" The Weekly Standard (2006).

Vidino, Lorenzo. "Aims and Methods of Europe's Muslim Brotherhood." In Current Trends in Islamist Ideology. Vol. 4. Washington, D.C.: Hudson Institute, November, 2006.

Whitaker, Raymond, and Francis Elliott. "Intelligence chiefs warn Blair of homegrown 'insurgency'." The Independent (2005). 